\title{
Product Quality, Sales Promotion, Distribution Channel and the Effect on the Level of Sales Volume Oyster Mushrooms in Kutalimbaru Subdistrict, North Sumatera Indonesia
}

\author{
Fauziah Agustini ${ }^{1, *}$, Sabda Dian Nuraini Siahaan ${ }^{1}$, Agus Rahmadsyah ${ }^{1}$, Sulaiman \\ Lubis $^{1}$ \\ ${ }^{1}$ Universitas Negeri Medan \\ ${ }^{*}$ Corresponding author.Email: fauziahagustini@unimed.ac.id
}

\begin{abstract}
The purpose of this research is to find out the influence of product quality, sales promotion, and distribution channel on the level of oyster mushroom sales volume in Kutalimbaru district, North Sumatra, Indonesia. Samples in this study amounted to 50 producers of oyster mushrooms. Data obtained through observations, interviews, literature studies, and the distribution of questionnaires. Data analysis techniques used are multiple regression analysis techniques. The results showed that there is an influence of product quality, sales promotion, and distribution channel of oyster mushrooms to the sales volume of oyster mushrooms in Kutalimbaru District, North Sumatra, Indonesia.
\end{abstract}

Keywords: Product Quality, Sales Promotion, Channel Distribution, Sales Volume

\section{INTRODUCTION}

Oyster mushroom or Pleurotus Ostreatus is quite liked by Indonesian people. This is because oyster mushrooms have a high protein source, are rich in vitamins and minerals, and are low in carbohydrates, fats, and calories. Based on data from the Agriculture Office of North Sumatra Province in 2013, there are only 5 districts/cities that produce mushrooms, namely Asahan Regency, Deli Serdang Regency, Langkat Regency, Tebing Tinggi City, and Binjai City. This indicates that there is still at least oyster mushroom cultivation for the province of North Sumatra, Indonesia.

In North Sumatra Micro, Small and Medium Enterprises (MSMEs) that produce the first oyster mushrooms were in Kutalimbaru District in 2012. the sales volume of oyster mushrooms decreased. This is a problem for the sale of oyster mushrooms in Kutalimbaru Subdistrict. If this condition continues the sale of oyster mushrooms may go bankrupt.

According to [8], "Sales volume is goods sold in the form of money for a certain period in which it has a good service strategy". Sales volume can be influenced by several factors, including product quality, sales promotion, and distribution channels. The problem of oyster mushroom quality that has been found is, the producers do not maintain the physical quality of oyster mushrooms, resulting in consumers are less interested in buying oyster mushrooms. The importance of maintaining the quality of oyster mushrooms is an advantage for an effort in increasing sales volume. Definition of product quality itself according to [8] the ability of a product in demonstrating its functions, this is included in the overall durability, reliability, accuracy, ease of operation, and repair of the product, as well as other product attributes

Sales promotions can also help in increasing sales volume. However, oyster mushroom producers in this location do not run sales promotions vigorously. The promotion is simple, namely only through the mouth to mouth between fellow consumers. Due to the lack of sales promotion, this causes oyster mushroom consumers only people who live around the sales location. Sales promotion according to [9] A key element in marketing campaigns as a collection of incentive tools that stimulate the purchase of products and suits faster and greater to consumers.

The oyster mushroom distribution channel is only managed by the producers themselves and can also be 
through agents. Producers also only sell oyster mushrooms to nearby traditional markets or sell them to sales agents. Furthermore, the sales agent also sells oyster mushrooms to the nearest traditional market so that the distribution channel of this oyster mushroom becomes very narrow. The definition of distribution according to [5] can be interpreted as marketing activities that seek to pioneer and facilitate the delivery of goods and services from producers to consumers so that their use is by the injured (type, price, quantity, place, and when needed).

Based on the problems that have been described before, this is what causes researchers to be interested to know the influence of product quality, sales promotion, and distribution channels on the level of oyster mushroom sales in Kutalimbaru District, North Sumatra, Indonesia.

\section{RESEARCH METHOD}

\subsection{Population and Sample}

The population in this study amounted to 50 producers in Kutalimbaru Subdistrict, North Sumatra, Indonesia. Sampling techniques of this research using total sampling so that the sample in this study amounted to 50 respondents.

\subsection{Data collection methods}

The method of data collection is as follows:

1. Observation, which is observing directly to the District Kutalimbaru North Sumatra, Indonesia.

2. Interview, which is doing a question and answer with oyster mushroom producers Kutalimbaru District North Sumatra, Indonesia.

3. Literature studies, i.e. data collected through journals and books related to research

4. Questionnaire or questionnaire, which is spreading the questionnaire to oyster mushroom producers Kutalimbaru District North Sumatra, Indonesia.

\subsection{Data Analysis Techniques}

\section{Multiple Linear Regression Analysis}

The analytical techniques used in this study are multiple regression analysis techniques. The models of multiple regression equations are:

$$
\mathrm{Y}=\mathrm{a}+\mathrm{b} 1 \mathrm{X} 1+\mathrm{b} 2 \mathrm{X} 2+\mathrm{b} 3 \mathrm{X} 3+\mathrm{e}
$$

Description:

$\mathrm{Y}=$ Sales volume

$\mathrm{a}=$ Constant

b1-5 = Independent variable regression coefficient

$\mathrm{X} 1$ = Product quality variable

$\mathrm{X} 2=$ Sales promotion variable

X3 = Variable distribution channel

\section{RESEARCH AND DISCUSSION RESULTS}

\subsection{Research Results}

Based on the results of the study, multiple regression equations such as table 1 , namely:

$\mathrm{Y}=3,050+0.266 \mathrm{X} 1+0.029 \mathrm{X} 2+0.483 \mathrm{X} 3+\mathrm{e}$

The explanation is as follows:

1. 0.266 means that each one-unit increase in product quality (X1) will cause sales volume to increase by 0.266 with other free variable conditions considered constant.

2. 0.029 means that each increase of one-unit promotion variable (X2) will cause sales volume to increase by 0.029 with other free variable conditions considered constant.

3. 0.483 means that each increase of one-unit variable distribution channel (X3) will cause the sales volume to increase by 0.483 with other free variable conditions considered constant.

4. 3050 means: if product quality (X1), sales promotion (X2), distribution channel(X3), then the sales volume on oyster mushroom products in Lau Bakeri Village is 3,050 .

\subsection{Coefficient of Determination (R2)}

Table 2 shows that adjusted R Square's determinant coefficient obtained is 0.417 , which means that $41.7 \%$ of sales volume variables are affected by product quality variables, sales promotions, distribution channels, while the remaining $58.3 \%$ is explained by the influence of other factors or variables outside the model such as individual sales, consumer satisfaction, the purchasing power of the community.

\subsection{Hypothesis Testing}

\subsubsection{Simultaneous Hypothesis Testing Using F Test}

Simultaneous significance test results can be seen in the following table:

Table 1. Multiple Linear Regression Equations

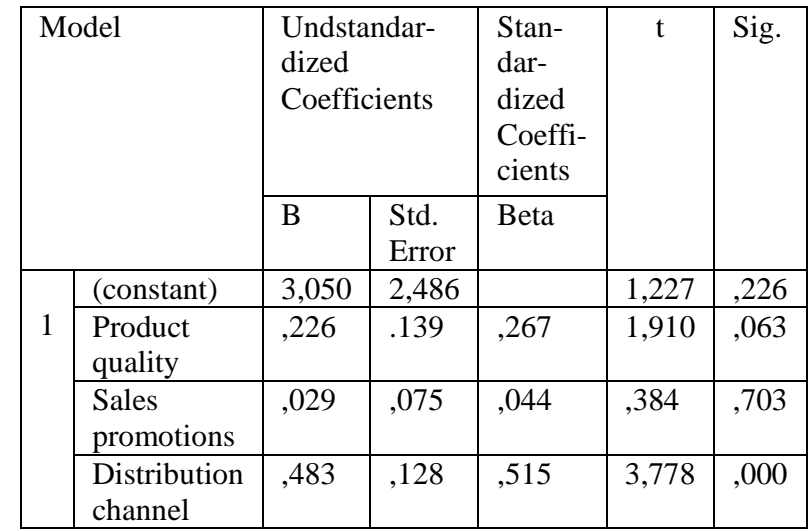


Table 2. Coefficient of Determination (R2)

\begin{tabular}{|c|c|c|c|c|}
\hline \multicolumn{5}{|c|}{ Model Summary ${ }^{b}$} \\
\hline Model & $\mathrm{R}$ & $\begin{array}{l}\mathrm{R} \\
\text { Square }\end{array}$ & $\begin{array}{l}\text { Adjusted R } \\
\text { square }\end{array}$ & $\begin{array}{l}\text { Std. Error of } \\
\text { the Estimate }\end{array}$ \\
\hline 1 &, $690^{\mathrm{a}}$ & ,476 & ,417 & 1,397 \\
\hline & \multicolumn{4}{|c|}{$\begin{array}{l}\text { Predicators: (constant), product quality, sales } \\
\text { promotions, distribution channel }\end{array}$} \\
\hline & \multicolumn{4}{|c|}{ Dependent variable: sales volume } \\
\hline
\end{tabular}

\subsubsection{Partial Hypothesis Testing Using t Test}

Based on table 3 the value of $\mathrm{F}$ calculates 8,000 with a significant level of 0.000 . F table 2.43. Therefore, $\mathrm{F}$ calculates the $>\mathrm{F}$ table then the criteria is H1 Accepted so that it can be stated that product quality, sales promotion, distribution channels, simultaneously have an effect and significant on sales volume.

\section{a. The Effect of X1 on Y}

The product quality variable is $\mathrm{t}$ calculate $1910>\mathrm{t}$ table 1679. This means that $\mathrm{H} 1$ is accepted so that product quality variables partially affect the sales volume of Oyster Mushroom products in Kutalimbaru District, Deli Medium.

\section{b. The Effect of $\mathrm{X} 2$ on $\mathrm{Y}$}

The sales promotion variable is t calculate $0.384<\mathrm{t}$ table 1.679. This means $\mathrm{H} 0$ is accepted so that the promotion variable partially has no effect on sales volume on Oyster Mushroom products in Kutalimbaru District Kab Deli Sedang.

c. X3 effect on Y

Variable distribution channel is $\mathrm{t}$ calculate $3778>\mathrm{t}$

Table 3. The ANOVA Test Result

\begin{tabular}{|c|c|c|c|c|c|c|}
\hline \multicolumn{7}{|c|}{ ANOVA $^{b}$} \\
\hline \multicolumn{2}{|c|}{ Model } & Sum of & Df & Mean & $\mathrm{F}$ & Sig. \\
\hline \multirow[t]{3}{*}{1} & $\begin{array}{l}\text { Regre } \\
\text { ssion }\end{array}$ & 78,097 & 5 & 15,619 & $\begin{array}{l}8,00 \\
0\end{array}$ & $\begin{array}{l}\text {, } 000 \\
\mathrm{a}\end{array}$ \\
\hline & $\begin{array}{l}\text { Resid } \\
\text { ual }\end{array}$ & 85,903 & 44 & 1,952 & & \\
\hline & Total & 164,000 & 49 & & & \\
\hline \multicolumn{7}{|c|}{ a. Dependent variable: sales volume } \\
\hline & \multicolumn{6}{|c|}{$\begin{array}{l}\text { Predicators: (constant), product quality, sales } \\
\text { promotion, distribution channel }\end{array}$} \\
\hline
\end{tabular}

table 1679. This means that $\mathrm{H} 1$ is accepted so that the variable distribution channel partially affects the sales volume of Oyster Mushroom products in Kutalimbaru District.

\section{DISCUSSION}

Based on the results of the study showed that the quality of the product affects the level of sales. The quality of oyster mushrooms affects the sales volume of oyster mushrooms in Kutalimbaru District, North Sumatra, Indonesia. This is by research conducted by [3], there is an influence of the quality of Jordan bread on the volume of Jordan bread sales on the CV. Minahasa Mantap Perkasa. Then the results of research that have been done by [4] also showed that the quality of Avanza car products affects the sales volume of Avanza car products.

The results showed that the promotion of oyster mushroom sales influenced the volume level of oyster mushroom sales in Kutalimbaru District, North Sumatra, Indonesia. Research conducted by [1] also showed that the promotion of Yamaha Mio motorcycle sales affects the volume of Yamaha Mio motorcycle sellers at PT. YAMAHA CENTRAL ALFA SCORPIO. Similarly, the results of research that have been conducted by [2] showed that there is an influence of sales promotion on sales volume in PT. Astra International Tbk-TSO Soetoyo Malang Branch.

Based on the results of the study showed that the distribution channel of oyster mushrooms affects the sales volume of oyster mushrooms in Kutalimbaru District, North Sumatra, Indonesia. This is in line with the results of research conducted by [3], namely the influence of Jordan's distribution channel on the volume of Jordan bread sales on the CV. Minahasa Mantap Perkasa. Furthermore, the results of research that have been done by [6] showed there is also the influence of distribution channels on sales volume at Sari Intan Manunggal Knitting Bandung

Partial hypothesis testing showed that sales promotions did not affect sales volume while distribution channels and product quality affected sales volume. Variables that have a more dominant influence on sales volume are distribution channel variables.

Based on the results of the analysis above, it is known that F-count $>$ F-table $(8,000>2.43)$ which indicates that the hypothesis is accepted. This means that product quality, sales promotion, and distribution channels simultaneously have a significant positive effect on sales volume.

The coefficient of determination (R2) indicates that the Adjusted R-value obtained is 0.417 , which means that $41.7 \%$ of sales volume variables are affected by product quality variables, sales promotions, and distribution channels while the remaining $58.3 \%$ is explained by the influence of other factors or variables outside the model.

\section{CONCLUSION}

There is an influence of product quality, sales promotion, and distribution channel of oyster mushrooms to the sales volume of oyster mushrooms in Kutalimbaru District, North Sumatra, Indonesia.

\section{REFERENCES}

[1] Arianty, Nel. The effect of the promotion mix to the sales volume of yamaha mio motorcycles in. Alfa 
scorpii, Central Yamaha. Jurnal Riset Akuntansi Dan Bisnis Vol 14 No. 1 March 2014

[2] Darmadi, Suharyono, Latief. The Effect of Sales Promotion on Sales (Case Study of PT. Astra International Tbk-TSO Soetoyo Malang Branch). Jurnal Administrasi Bisnis. Vol. 2 No. 1 May 2013

[3] Mokalu. A. Tumbel., M.D. Walangitan. The Effect of Product Quality, Price and Distribution on Sales Volume of Jordan Bread CV. Minahasa Mantap Perkasa. ISSN 2303-1174 Jurnal EMBA. Vol.3 No.1 March 2015. Hal. 254-265

[4] Kodu, Sarini. Price, Product Quality and Service Quality Influence on Toyota Avanza Car Purchase Decisions. ISSN 2303-1174. Jurnal EMBA. Vol.1 No.3 September 2013, pp. 1251-1259

[5] Fandy Tjiptono. Marketing Strategy, Edition-3. CV. ANDI OFFSET. Yogyakarta: ANDI. 2008.

[6] Rachman, Yuningsih, The Effect of Distribution Costs and Distribution Channels on Sales Volume (Study on Sari Intan Manunggal Knitting Bandung) Journal Riset Akuntansi Dan Bisnis.Vol 10 No .2 / September 2010

[7] Kotler, Philip and Gary Armstorng. Principle of Marketing. $15^{\text {th }}$ edition. New Jersey: Pearson Prentice Hall. 2014.

[8] Kotler, Armstorng. Marketing Principles 2. Edition 12. Jilid 1. Jakarta: Erlangga. 2008.

[9] Kotler dan Keller. Marketing Management. Jilid I. Edition 13. Jakarta: Erlangga. 2009. 